\title{
On-board Protection of Merchant Vessels from the Perspective of International Law
}

\author{
Birgit Feldtmann*
}

\section{Abstract}

The power to regulate on-board protection of merchant vessels lies with the flag state. However, the national models of regulation are not developed in a unilateral vacuum. In fact, the whole concept of flag state jurisdiction and legislative power has to be understood and exercised on the national level in close relation with the general regime of the international law of the sea. The aim of the article is therefore two-fold: first, it aims to provide a background for the country reports in this special issue by giving a brief insight into the problem of piracy in the twenty-first century and the international approaches towards this problem. Here the article also provides an insight into the legal background by presenting the concept of piracy in the law of the sea and connected law enforcement powers. Thus, this part of the article provides the overall context in which the discussions concerning on-board protection and the development of national regulations have occurred. Second, the article analyses the issue of on-board protection from the perspective of the legal framework in international law, as well as relevant international soft-law instruments, influencing the development on the national level. On-board protection of vessels as such is not regulated in the international law; however, international law provides a form of general legal setting, in which flags states navigate. Thus, this article aims to draw a picture of the international context in which flags states develop their specific legal approach.

Keywords: Piracy, international law, law of the sea, onboard protection of merchant vessels, use of force

\section{Introduction}

As mentioned in the introduction to this special issue, the power to regulate on-board protection of merchant vessels is placed on the flag state level. This does not mean that national models of regulation are developed in a unilateral vacuum. On the contrary, it can be argued that the whole concept of flag state jurisdiction and legislative power has always to be understood and exercised on the national level in close relation with the general regime of the international law of the sea and the particular system of governance set out in the UN Convention on the Law of the Sea (UNCLOS). ${ }^{1}$ Furthermore, while the issue of on-board protection has to be - and in many flag states is - addressed on the national level, it has also been a topic high on the international agenda. It has been - and still is - a subject of international discussions, considerations and also of some forms of rulemaking in different international fora. Against this background, it seems rather necessary to introduce a special issue on national models of regulation of on-board protection of merchant vessels with an international perspective.

The aim of this contribution is basically two-fold. First, it aims to provide a background for the four country reports in this special issue by giving a brief insight into the problem of piracy in the twenty-first century and the international approaches towards the problem. Second, this article provides an overview on the issue of onboard protection of merchant vessels from the perspective of the international law framework, as well as relevant international soft-law instruments, influencing the development on the national level. In this context, the contribution also provides an insight into the legal background by presenting the concept of piracy in the international law of the sea and connected law enforcement tools. This might not seem directly relevant in connection with the specific questions of on-board protection by private actors; however, it is relevant as the over-all context, in which the discussion on on-board protection is taken. In addition, as the country reports in this special issue illustrate, not all flag states have been initially turning to a model of regulation which is based on the involvement of private actors.

The international law perspective of this article raises a number of central questions, such as the use of force and the right to self-defence, which are at the core of the issues at stake in connection with on-board protection. On-board protection of vessels as such is not explicitly regulated in the international law of the sea; however, international law provides a kind of general legal setting in which flag states navigate. Thus, this contribution aims to draw an overall picture of the international context in which flag states developed their specific legal approach towards on-board protection. 


\section{The Somali Problem of Piracy and the Approach of the International Community}

The development of the models of regulation of onboard protection of merchant vessels in Denmark, Germany, Italy and the Netherlands is closely linked to the development of the problem of piracy in the Horn of Africa region at the beginning of the twenty-first century. While piracy was never fully eradicated on the oceans, in the legal debate of the twentieth century it was - as mentioned in the introduction to this special issue - primarily perceived as a historical phenomenon. ${ }^{2}$ At the start of the new millennium, piracy and other forms of attacks against ships were, however, not necessarily perceived as a historical phenomenon by seafarers. It was a form of maritime crime occurring in different regions of the world, such as the waters in South-East Asia (Malacca Strait), the Caribbean and in West and East African waters and therefore a risk to be considered for seafarers, ship owners and insurers. Nevertheless, it was particular the Somali problem of piracy, meaning piracy activities launched from Somalia into the waters of the Horn of Africa region and wider Indian Ocean region, which put piracy on the international agenda and, in particular, triggered the development of national models of on-board protection of merchant vessels.

\subsection{The Somali Problem of Piracy}

The reasons for focusing on the East African problem of piracy are multifaceted, but could be summed up by the following points: first, from the early years of the millennium and up to 2010-2011, the world witnessed a substantial increase in piracy attacks and hijackings in the waters of the region of the Horn of Africa. ${ }^{3}$ At the same time, the radius of operation of Somali pirates was substantially widened. While the first attacks were registered close to certain parts of the Somali coast and in rather limited geographical areas (mostly in the Somaliland and Puntland coastal areas), attacks by Somali pirates were later registered in a vast area of the Indian Ocean. The widening of radius of operation of Somali pirates was connected to the pirates' use of - often hijacked - mother ships as a base for their illegal activity. The development of the Somali problem of piracy up to March 2010 was very illustratively visualised by EU NAVFOR and published in an Internet article by the $\mathrm{BBC}^{4}$ :

2. See R. Geiß and A. Petrig, Piracy and Armed Robbery at Sea; the Legal Framework for Counter-Piracy Operations in Somalia and the Gulf of Aden (Oxford, 2011), 40, who are referring to the discussions under the UN Conference on the Law of the Sea.

3. See B. Feldtmann, 'Fighting Maritime Piracy; on Possible Actions and Consequences', in T. Eger, Oeter \& Voigt (eds.), Economic Analysis of International Law; Contributions to the 13th Travemünde Symposium on the Economic Analysis of Law, 29-31 March 2012 (2014) 175

4. BBC News, 1 April 2010, 'Kenya Ends Trials of Somali Pirates in Its Courts', available at: http://news.bbc.co.uk/2/hi/africa/8599347.stm (last visited 1 April 2019).

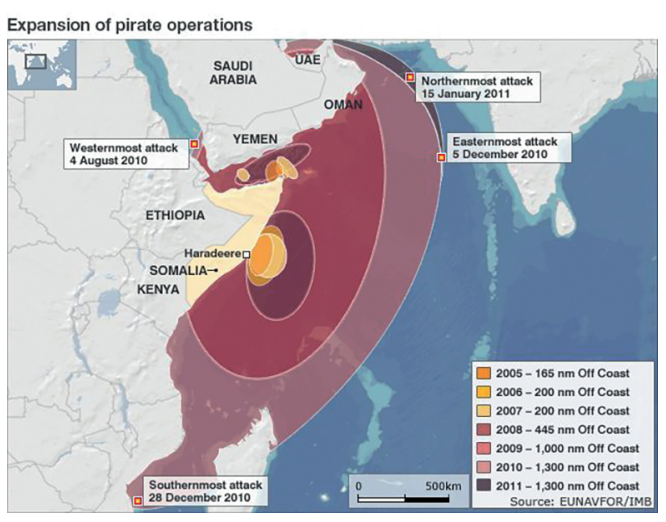

In addition, part of the wider context of the Somali problem of piracy is that the increase in piracy attacks happened in a geographical area which is quite crucial for world trade: the passage from Asia via the Suez Channel to Europe. It was estimated in 2005-2006, when Somali piracy was seriously starting to present itself as a growing problem, that about 7.5 per cent of the world's seaborne transportation - about 18,000 vessels per year - navigated through the Suez Channel. ${ }^{5}$

The second reason for focusing on the Somali problem of piracy is that Somalia, the state in which the pirates were based and from which their unlawful activities were launched, could be - at least at that time - be categorised as a 'failed state'. ${ }^{6}$ In the context of counter pira$\mathrm{cy}$, this means that the coastal state, which in the general regime of the law of the sea should play a crucial role in fighting piracy, was unable to secure its own waters, prevent its citizens committing acts of piracy or to initiate acceptable criminal proceedings against suspected pirates. ${ }^{7}$ Thus, Somalia was basically allowing the international community take the lead. ${ }^{8}$

Third, Somali pirates developed a specific modus operandi for their criminal activity, which not only included different forms of violence and robbery against ships but also the long-term hijacking of vessels and kidnapping of crews with the aim of obtaining the payment of a substantial ransom by the ship owner. Thus, Somali piracy developed into 'big business', supported by well-organised criminal networks on the mainland. ${ }^{9}$

5. Berlingske, 13 September 2006, 'Fakta: Suez-kanalens historie', available at: https://www.berlingske.dk/videnskab/fakta-suez-kanalenshistorie (last visited 1 April 2019)

6. J.P. Pham, 'The Failed State and Regional Dimensions of Somali Piracy', in B. van Ginkel and F.-P. v.d. Putten (eds.), The International Response to Somali Piracy; Challenges and Opportunities (2010) $31 \mathrm{ff}$.

7. See Feldtmann, above n. 3, 174.

8. See further below in Section 3 on SC resolution.

9. See UNDOC, 25 May 2011, 'Awash with Money - Organized Crime and Its Financial Links to Somali Piracy', available at: https:// www.unodc.org/unodc/en/frontpage/2011/May/awash-withmoney---organized-crime-and-its-financial-links-to-somali-piracy.html (last visited 1 April 2019). On the cost connect to maritime piracy see, e.g.: Oceans Beyond Piracy, 'The Economic Cost of Somali Piracy, 2012' (2013), available at: http://oceansbeyondpiracy.org/sites/default/files/ attachments/View\%20Full\%20Report_3.pdf (last visited 1 April 2019). 


\subsection{The International Approach towards the Somali Problem of Piracy}

The response of the international community and the maritime stakeholder towards the Somali problem of piracy has been multifaceted. The overall discussions and coordination of the combined efforts against Somali piracy take part under the auspices of the Contact Group on Piracy off the Coast of Somalia (CGPCS) ${ }^{10}$ which over time has been divided into a number of (changing) specific working groups. The CGPCS can be described as a governance mechanism that was created to ensure coordination of the responses to Somali piracy off the coast of Somalia. States, international organisations, NGOs and the industry use this forum to develop common and coordinated responses to piracy. ${ }^{11}$ The CGPCS was created in 2009 pursuant to UNSC Resolution 1851, which encourages '... all States and regional organizations fighting piracy and armed robbery at sea off the coast of Somalia to establish an international cooperation mechanism to act as a common point of contact between and among states, regional and international organizations on all aspects of combating piracy and armed robbery at sea off Somalia coast; ....' The CGPCS was subsequently initiated by twenty-four states and developed over time into a strong governance mechanism including seventy states and nineteen organisations (both inter-governmental organisations and NGOs/private organisations). ${ }^{12}$ The approaches discussed under the CGPCS and implemented under different schemes ${ }^{13}$ are basically based on three pillars.

First, international naval cooperation to combat piracy and to secure a safe transfer in the Internationally Recommended Transit Corridor (IRTC) in the Gulf of Aden and the Indian Ocean. There have been three major international naval operations which at least in part had a counter-piracy mandate: Combined Task Force (CFT 151) under the multinational naval partnership Combined Maritime Force (CMF), NATO's Operation Ocean Shield and EU NAVFOR's operation Atalanta. Furthermore, a number of states, for example India, South Korea, Russia and China, which are not directly involved in these multinational operations, have deployed naval vessels in the region and have been closely working with the other stakeholders to combat piracy. ${ }^{14}$ To enhance the cooperation and communication and to avoid conflict between the different stakeholders an informal mechanism was established: the

10. The author has since 2013 been involved in the work under CGPCS as a legal advisor to the legal working group (WG2 on legal issues), a participator in the Lessons Learned Project and a member of the Danish delegation.

11. See information on the GCPCS's website, available at: www.lessonsfrompiracy.net (last visited 1 April 2019).

12. C. Bueger, 'Responses to Contemporary Piracy: Disentangling the Organizational Field', in D. Guilfoyle (ed.), Modern Piracy: Legal Challenges and Responses (2013) 98.

13. Ibid., 96-113

14. See M. Buch, 'Managing Pirates; Mandate, Detention and International Aspects', in P. Vedel Kessing and A. Laursen (eds.), Robust mandat juridiske udfordringer ved danske militære missioner $i$ det 21. århundrede (2016) 323 ff.; B. Feldtmann, 'Jura som et led i dansk aktivistisk udenrigspolitik til søs', Økonomi \& Politik 2017, 1415 (2017).
Shared Amareness and Deconfliction Mechanism (SHADE) was established in 2008 to bring together both the multinational counter-piracy operations and states operating independently. One major tool under SHADE is the military communication system MERCURY, which is a kind of 'chat room type' communication tool accessible for all SHADE members enabling direct and 'real time' communication. ${ }^{15}$ The international naval cooperation in the region is rather striking in this respect, as it involves various states cooperating and working quite closely together, allied by the aim to combat piracy; states that in other geopolitical contexts are not necessarily cooperating at all.

The second pillar in the effort to deal with the problem at hand is capacity building on land. This approach is based on the analysis that piracy is a crime which is committed at sea, but which has its root causes on land. Thus, a long-term, sustainable solution to Somali piracy depends not only on repressive operations at sea but also on long-term capacity building at land to deal with the piracy-supporting structures and to provide alternative occupation for the local population. It also involves the establishment of reliable law enforcement structures based on the rule of law on land and at sea. ${ }^{16}$

The third pillar is self-protection of the shipping industry. The shipping industry and other maritime stakeholders have developed a number of recommendations and guidelines to prepare vessels and crews for navigating in high-risk areas and to prevent successful piracy attacks. ${ }^{17}$ Those recommendations include, for example, guidelines on threat assessment, navigation, training and the 'hardening of the vessel'. The 'hardening' can for instance be archived by securing the vessel against unwanted access with razor wire and other measures such as water spray rails. One possible means in the industry's self-protection approach is the use of armed on-board protection either by Vessel Protection Detachment (VPDs) or by Privately Contracted Armed Security Personnel (PCASPs) provided by a Private Maritime Security Company (PMSC). The issue of on-board protection and, in particular, the use of PCASPs, is far from uncontroversial, and guidelines usually avoid explicitly recommending or encouraging the use of PCASPs. The shipping industry's Best Management Practices to Deter Piracy and Enhance Maritime Security in the Red Sea, Gulf of Aden, Indian Ocean and Arabian Sea, version 5 from Fune 2018 (BMP5) is, for example, stating that it 'does not recommend or endorse the general use of PMSCs on-board merchant ships; this is a decision taken by the individual ship operators where

15. See C. Bueger, 'Responses to Contemporary Piracy: Disentangling the Organizational Field', in D. Guilfoyle (ed.), Modern Piracy: Legal Challenges and Responses (2013) 106.

16. See, e.g., the Danish Counter-piracy Strategy for the years 2011-2014: 'Strategy for the Danish counter-piracy effort 2011-2014', 29-39. The Strategy is available at: http://um.dk/en/foreign-policy/piracy/ (last visited 1 April 2019)

17. See, e.g., BMP 5 (Best Management Practices to Deter Piracy and Enhance Maritime Security in the Red Sea, Gulf of Aden, Indian Ocean and Arabian Sea, version 5 from June 2018), which will be briefly introduced below. 
permitted by the ship's Flag State.... ${ }^{18}$ However, it can be argued that some factors, for example, insurance policies, might in fact encourage or even prescribe the use of PCASPs. ${ }^{19}$ The issues of on-board protection in general and PCASPs in particular has also been on the international agenda under the CGPCS. Real consensus was never reached in this matter apart from the general consensus that the issue first of all should be dealt with at the flag state level. Nevertheless, the issue of an international legal framework for PCASPs is still occasionally raised in international discussions. ${ }^{20}$

In conclusion, it can be argued that the combined efforts of all of the stakeholders against Somali piracy under the three pillars have been a general success: at the height of Somali piracy in January 2011, 736 hostages and 32 ships were held by pirates, and by October $2016,{ }^{21}$ no hostages or ships were held. This could lead to the conclusion that the problem has been solved and no further action is needed. This is a conclusion which is feared and challenged by the shipping industry, which has pointed out that the problem is not solved but has only been effectively contained. If the efforts are terminated, Somali piracy would most likely regain strength because its root causes and supporting structures still exist on the mainland. This conclusion is supported by the fact that Somali pirates managed to hijack a vessel in March 2017 and that there has been an increase in the registration of piracy attacks in 2017 and 2018. ${ }^{22}$ Also in 2019 attacks by Somali pirates have been registered. ${ }^{23}$

It can also be argued that the positive effects of the three-pillar approach might have an unintended side effect with regard to on-board protection. It seems that the states' willingness to engage in counter-piracy operations is decreasing. Fewer vessels are deployed in the region, and NATOs Operation Ocean Shield was terminated at the end of 2016. EU NAVFOR's operation Atalanta has been extended to the end of 2020; however, the naval capacity under Atalanta has been reduced quite substantially in recent years. ${ }^{24}$ This means that the shipping industry's efforts are even more crucial than before and might lead to the mind-set that on-board protection is unavoidable.

18. BMP 5, Section 5 (Ship Protection Measures), 22.

19. The role of insurers in connection with the problem of piracy is analysed by A. Shortland, Kidnap; Inside the Ransom Business (2019).

20. See, e.g., Final Communique of the 21st Plenary Session of the CGPCS (12-13 July 2018), para. 20, available at: www.lessonsfrompiracy.net/ files/2018/07/Communique-of-the-CGPCS-21st-Plenary-Session.pdf (last visited 1 April 2019).

21. EU NAVFOR, Operation ATALANTA, available at: https://eunavfor.eu/ mission/ (last visited 1 April 2019)

22. See Danske Rederier (Danish Ship Owners), Policy Paper 'Piracy', November 2018.

23. EU NAVFOR, 24 April 2019, 'Piracy Attack Deterred off the Coast of Somalia', available at: https://eunavfor.eu/piracy-attack-deterred-offthe-coast-of-somalia/ (last visited 1 May 2019).

24. For example are currently only two naval vessels deployed under Atalanta, see: EU NAVFOR, available at: https://eunavfor.eu/deployedunits/surface-vessels/\#news-tabs (last visited 1 April 2019).

\section{The Concept of Piracy in International Law and Connected Obligations and} Powers

As mentioned in the introduction to this special issue, piracy is by far not a new concept; not in practical terms for seafarers or in a legal sense. Today's perception and codification of piracy dates back to the legal discussions and consideration that took place at the beginning of the twentieth century. Piracy and related obligations and enforcement powers were first codified in the 1958 Convention on the High Seas, which was based on the Harvard Draft Convention on Piracy of 1932. The piracy provisions of the 1958 Convention on the High Seas were subsequently incorporated into UNCLOS with only minor changes. ${ }^{25}$

The starting point for today's international approach towards piracy is set out in Article 100, which emphasises that all states '.. shall cooperate to the fullest possible extent in the repression of piracy ...'. The concept of piracy in international law is defined in Article 101 ('definition of piracy'):

Piracy consists of any of the following acts:

a. any illegal acts of violence or detention, or any act of depredation, committed for private ends by the crew or the passengers of a private ship or a private aircraft, and directed:

i. on the high seas, against another ship or aircraft, or against persons or property on board such ship or aircraft;

ii. against a ship, aircraft, persons or property in a place outside the jurisdiction of any State;...

The definition in Article 101 entails a number of elements that are central in order to determine whether a certain activity is piracy in the sense of international law or not. Subsections (b) and (c) of Article 101, here not quoted, are widening the piracy definition to certain acts of participation, inciting or facilitating. ${ }^{26}$ The determination of an act as piracy according to Article 101 is a precondition for states' legitimate use of UNCLOS' counter-piracy powers which are granted in the following articles. ${ }^{27}$ Piracy is in Article 101 defined by a number of unlawful acts (acts of violence, detention or depredation) which are carried out from one ship to another (so-called two-ship requirement). These two criteria have not given rise to real challenges in the context of problem in the Horn of Africa region, as the attacks are usually committed from small skiffs or open whalers under the use of firearms or rocket propelled grenades

25. See Geiß and Petrig, above n. 2, $37 \mathrm{ff}$.

26. T. Treves, 'Piracy and the International Law of the Sea', in D. Guilfoyle (ed.), Modern Piracy; Legal Challenges and Responses (2013) $120 \mathrm{f}$.

27. Geiß and Petrig, above n. 2, $59 \mathrm{ff}$. 
(RPGs). ${ }^{28}$ More challenging is Article 101's requirement that these acts be committed 'for private ends'. The question at hand is, albeit slightly simplified, whether the criterion excludes all actions that have not exclusively an enrichment purpose but, for example, are carried out on the basis of political/terrorist motives. The opposite argumentation is that the criterion should be understood as a delimitation between state-initiated or state-sanctioned actions and actions made by private individuals. ${ }^{29}$ The question of the interpretation of the 'for private ends' criterion is relevant in the context of Somali piracy as it would be decisive for the determination of whether the international community is dealing with piracy in UNCLOS' sense or not if there could be a proven connection between Somali pirate groups and the terrorist organisation Al Shabaab. In practice, however, it is widely assumed today that Somali pirates fall under the 'for private ends' criterion and the international counter-piracy operations are based on that assumption. ${ }^{30}$ The last central criterion in Article 101 is that the specific acts must be committed 'on the high seas' or 'outside the jurisdiction of any state'. This means that piracy can only be committed outside territorial waters. If the same actions are committed within territorial waters, these are typically referred to as 'armed robbery at sea' or similar terminology. ${ }^{31}$ Against those acts, which are very similar to piracy but committed in territorial waters, UNCLOS' counter-piracy powers cannot be used. The reason for this geographical limitation in the definition of piracy is that actions in territorial waters in principle are subjected to the coastal state's jurisdiction and enforcement powers and thus not a shared responsibility of all states.

In connection with piracy in the Horn of Africa region, the geographical limitation of UNCLOS has to a certain extent been evaded, since two Security Council Resolutions, SC Res. 1846 (2008) and 1851 (2008), blur the difference between piracy and 'armed robbery at sea' by allowing, under specified circumstances, the possibility of counter-piracy operations by other states both in Somali waters and on Somali soil. ${ }^{32}$ The specific powers granted by SC Res. 1846 (2008) and 1851 (2008) have been time-limited, but are frequently renewed, latest with SC Res. 2442 (2018). ${ }^{33}$

\subsection{UNCLOS' Counter-piracy Powers}

The starting point for the states' counter-piracy powers is that there is an initial suspicion of piracy or a suspicion that a given ship is a 'pirate ship' (Art. 103), meaning it is a ship being used for piracy activities as defined in Article 101 or is controlled by pirates. The initial requirement for using UNCLOS' counter-piracy powers against another ship and the persons on board is a

28. See BMP 5, 4.

29. See D. Guilfoyle, 'Counter-Piracy Law Enforcement and Human Rights', 59(1) International and Comparative Law Quarterly 143 (2010).

30. Feldtmann, above n. 3, 179.

31. Ibid., $178 \mathrm{f}$.

32. Geiß and Petrig, above n. 2, $70 \mathrm{ff}$.

33. Resolution 2442 (2018), para. 14, from November 2018 is granting the powers for further thirteen months. 'reasonable ground for suspecting' an engagement in piracy. If this suspicion is confirmed, UNCLOS grants a number of specific law enforcement powers, such as rights to visit, inspection and boarding, and the search and seizure of items on board (Arts. 105 and 110). The general principle here is that the enforcement powers are extended proportionally to an increasing confirmation of the suspicion. If the suspicion cannot be confirmed in due course, no further law enforcement actions can be taken. ${ }^{34}$ If the suspicion is confirmed, Article 105 grants every state the right to 'seize a pirate ship ... and arrests the persons'. The Convention does, however, not contain any further provisions on such arrest; for example, the issue of legal control in connection with detention is not addressed in UNCLOS. ${ }^{35}$ UNCLOS also states that 'The courts of the State which carried out the seizure may decide upon the penalties to be imposed.... This means that UNCLOS' provisions include an explicit right for states to arrest persons suspected of piracy and to initiate criminal proceedings in the state's domestic courts. While the wording in UNCLOS could indicate an exclusive right of the seizing state, state practice indicates that the right to initiate criminal proceedings is not understood as being exclusively granted to the seizing state and suspected pirates have in fact been transferred between different states on a somewhat questionable legal basis. ${ }^{36}$

While UNCLOS provides provisions on a number of counter-piracy powers, it does not explicitly deal with the question of the use of force in counter-piracy operations or otherwise. It is, however, argued with reference to other international legal instruments, in particular the nonbinding $U N$ Basic Principles on the Use of Force and Firearms by Law Enforcement Officials (UN Basic Principles), ${ }^{37}$ and to the case law of the International Tribunal of the Law of the Sea (ITLOS), in particular the $M / V$ Saiga Case No. 2,38 that the use of proportional force as a last resort is implicitly permitted under UNCLOS and therefore also permitted in the context of counter-piracy operations. ${ }^{39}$ In relation to the question of the use of force in counter-piracy operations, it is relevant to point out that UNCLOS emphasises that counter-piracy operations can only be carried out by state actors and in particular by military entities. Article 107 provides that

34. B. Feldtmann, 'Pirateribekæmpelse i komplekse juridiske farvande', in S. Bønsig, T. Elholm, S.S. Jakobsen \& L.W. Lentz (eds.), I forskningens og formidlingens tieneste (2018) 101

35. Ibid., $105 \mathrm{ff}$.

36. See A. Petrig, Human Rights and Law Enforcement at Sea; Arrest, Detention and Transfer of Piracy Suspects (2014) $315 \mathrm{ff}$.

37. The UN Basic Principles are a 'soft law instrument', which was adopted by consensus of 127 states in 1990, see A/CONF.144/28/Rev1 (7 September 1990).

38. M/V Saiga (No.2), San Vincent and the Grenadines v Guinea, ITLOS Case No. 2 (1999).

39. Geiß and Petrig, above n. 2, 69. See also D. Guilfoyle, 'Prosecuting Somali Pirates: A Critical Evaluation of the Options', 10(4) Journal of International Criminal Justice 773-4 (2012); D. Guilfoyle, 'The Use of Force against Pirates', in M. Weller (ed.), The Oxford Handbook of the Use of Force in International Law (2015) $1063 \mathrm{ff}$. 
A seizure on account of piracy may be carried out only by warships or military aircraft, or other ships or aircraft clearly marked and identifiable as being on government service and authorized to that effect.

This means that only military units, in practice mainly navies, are granted UNCLOS' law enforcement powers and therefore are enabled to conduct counter-piracy operations. In connection with the military's role in combating piracy it should be noted that the use of UNCLOS' powers against piracy happens in a law enforcement context and not in the context of an armed conflict. This means that it is a policing task, an issue of crime control and that 'the laws of war' do not apply. ${ }^{40}$ The overall framework for a given counter-piracy operation will be further elaborated and concretised in the specific mandate of the operation and its associated Rules of Engagement, and further in the mandate defined by the national parliament for its own forces. ${ }^{41}$

The fact that UNCLOS places the counter-piracy powers, and therefore indirectly also the connected right to use proportional force, on naval entities does not exclude the existence of an individual right of selfdefence against a piracy attack. The concept of individual self-defence raised here is not to be mixed with the concept of the state's right to self-defence under Article 51 of the UN Charter. The individual right of selfdefence is as a starting point based in domestic law (e.g. in the flag states' legislation or legal principles); thus, certain differences in the scope and application of the right to self-defence might occur. ${ }^{42}$ It can be assumed that many flag states might permit the use of deadly force in self-defence as a last response to an imminent danger to life, but it is more questionable if states, for example, also permit the use of deadly force to defend property. ${ }^{43}$

The individual right to self-defence as a legal concept is not only rooted in a given state's national legal system but is also accepted as a concept in international law, for example, in Article 31(1) of the Rome Statute. ${ }^{44}$ From a general perspective, it can be argued that the individual right to self-defence is (indirectly) based on, or at least closely connected to, the individual right to life. The line of thought can be summarised as follows: Article 2 of the European Convention on Human Rights (ECHR) is protecting the right to life, both of the 'innocent'

40. M. Buch, 'Håndtering af pirater; mandat, frihedsberøvelse og internationale aspekter', 330 ff. and L. Plum, 'Håndtering af pirater; tilbageholdelse/frihedsberøvelse/varetægtsfængsling, retsforfølgning m.v.', 349 ff., both in P. Vedel Kessing and A. Laursen (eds.), Robust mandat; juridiske udfordringer ved danske militære missioner i det 21. århundrede (2016). See also D. Guilfoyle, 'The Laws of War and the Fight against Somali Piracy: Combatants or Criminals', 11 Melbourne Journal of International Law s. 1 ff. (2010) and C. Oehmke, Der Einsatz privater Sicherheitsdienste auf Handelsschiffen zur Abwehr gegen Piraterie (2016) 137-72.

41. See Buch, above n. 40, $322 \mathrm{ff}$. and Feldtmann, above n. 3, $192 \mathrm{ff}$

42. See Oehmke, above n. 40, 184-5.

43. See Guilfoyle, above n. 39, 1067-1068.

44. Rome Statute of the International Criminal Court (17 July 1998; in force on 1 July 2002; United Nations, Treaty Series, Vol. 2187, No. 38544 (last amended 2010). citizen and the 'wrong doer'. Article 2(II) is explicitly stating that the taking of a life by a state representative '...shall not be regarded as inflicted in contravention of this article when it results from the use of force which is no more than absolutely necessary ... in defence of any person from unlawful violence'. This implies that the protection of the individual right to life of the 'innocent victim' can justify the taking of the life of the 'wrongful attacker'. Article 2(II) is directed at states, but it can be argued that the provision is also indirectly implying that there is a right to individual (personal) self-defence. It is in this context argued that human rights law seems to indicate that states actually may not prohibit proportional individual self-defence altogether; however, the right to life of the 'wrong doer' implies that states must ensure tight, proportional boundaries to individual selfdefence rights. ${ }^{45}$

The issue of the individual right to self-defence was also raised in the legal debate under the discussions under the ILC in connection with Article 45, which is the predecessor of UNCLOS's Article 107. Under the discussions, it was emphasised that the placing of counterpiracy powers exclusively on states, represented by military entities, does not apply 'in the case of a merchant ship which has repulsed an attack by a pirate ship and, in exercising its right of self-defence, overpowers the pirate ship and subsequently hands it over to a warship.... This is not a "seizure" within the meaning of this article. ${ }^{46}$ This statement is interesting for at least two reasons; first, it confirms that the counter-piracy powers granted to states do not exclude the exercise of the individual right to self-defence against piracy attacks. It is accepted that merchant ships (e.g. the persons on board) have a right to self-defence and can exercise this right; this is a crucial precondition for the employment of PCASPs on merchant vessel. Second, it places a right to a civil arrest on non-state actors exercising the right of self-defence.

\subsection{SUA Convention}

The counter-piracy powers under UNCLOS are supplemented by other international legal acts. One legal instrument, which is of special importance in the Horn of Africa context is the Convention for the Suppression of Unlawful Acts against the Safety of Maritime Navigation (SUA Convention). ${ }^{47}$ The SUA Convention is not directly aimed against acts of piracy, but more generally against unlawful attacks against ships; its history is closely linked to the Achille Lauro incident of 1985, which highlighted some limitations of the existing regulatory system. ${ }^{48}$ The background of the SUA Convention is thus linked to terrorist attacks against ships and this background is also evident from its preamble. This

45. See J.A. Hessbruegge, Human Rights Standards for Self-Defense between Private Persons (2017).

46. ILC, 'Articles Concerning the Law of the Sea with Commentaries', 2 Y.B Int'I L. Comm'n 283 (1956).

47. Convention for the Suppression of Unlawful Acts against the Safety of Maritime Navigation (SUA Convention), adopted 10 March 1988, 1678 U.N.T.S. 221.

48. Geiß and Petrig, above n. 2, 40. 
does not mean that the scope of the SUA Convention is limited to terrorist activities; it is generally aimed at unlawful acts against safe navigation. Those acts can be acts covered by UNCLOS Article 101, but the SUA Convention covers also other illegal acts against ships, for example, internal attacks (e.g. attacks by passengers on board) which would fail the two-ship requirement in the definition of piracy in Article 101. ${ }^{49}$

One issue that has been raised in connection with the SUA Convention's role in combating piracy is whether the Convention as such can be used by state actors in a counter-piracy context. The background for this discussion is that the SUA Convention in Article 2 states that the Convention does not apply to warships and other state-owned ships. It is, however, argued that this restriction is aimed at the group of vessels that the Convention is seeking to protect and which are the potential targets of the Convention's considered forms of unlawful attacks. ${ }^{50}$ In other words, the SUA Convention aims to protect civilian ships - not state ships. The law enforcement obligations and powers provided for in the SUA Convention are in contrast targeted at states and will in practice be used by state actors, including warships and other state ships. The practices of states in the Horn of Africa region illustrate that the SUA Convention is considered by many states as a supplement to the counter-piracy powers under the UNCLOS regime, for example, in connection with the handling of suspected pirates. ${ }^{51}$ It can, however, be questioned whether the SUA Convention adds anything to UNCLOS' enforcement powers, since the SUA Convention does not contain more specific law enforcement powers such as the stopping and boarding of foreign ships. ${ }^{52}$ On the other hand, state practices seem to indicate that states/state authorities explicitly invoke the provisions in the SUA Convention when dealing with piracy cases, for example, in connection with the transfer of suspected pirates. ${ }^{53}$

Furthermore, the SUA Convention places a number of obligations on states; for example, Article 5 of the Convention requires that states criminalise a number of actions that are further defined in Article 3. Those actions, which each state has to criminalise in its own domestic legal system, include various forms of attacks against ships or their crews or passengers. These actions can be piracy but also other illegal acts outside the scope of the definition of piracy in Article 101 in UNCLOS. The illegal acts concerned include also acts committed in territorial waters if the affected ship has sailed, or intends to sail, in or out of a given state's territorial

49. D. Guilfoyle, 'Treaty Jurisdiction over Pirates: A Compilation of Legal Texts with Introductory Notes', report prepared for Contact Group on Piracy off the Coast of Somalia, 26-27 August 2009 (New York: Contact Group on Piracy off the Coast of Somalia, 2009), 12.

50. See Guilfoyle, above n. 29, 149; Petrig, above n. 36, 44

51. See A. Petrig, above n. 36,235 , on Art. 7 of the SUA Convention as a legal basis for detention.

52. See M. Frostad, Voldelige Hav; Pirateri og Jus (2016) $120 \mathrm{f}$.

53. See A. Petrig, above n. 36, 43-47, who herself is concluding that states cannot use Art. 8 of the SUA Convention as a basis for a delivery/transfer. waters (Art. 4). States are obliged not only to criminalise these actions but also to have criminal jurisdiction in a number of specified situations. ${ }^{54}$

The SUA Convention, as mentioned above, does not directly grant states specific law enforcement powers to arrest suspected perpetrators with the exception of Article 7(2) which obligates states '..., in accordance with its law, take him into custody or take other measures to ensure his presence for such time as is necessary to enable any criminal or extradition proceedings to be instituted', if another state issues an arrest warrant. The procedure for such detention must be in accordance with the national law of that state. The overall aim of the SUA convention is that there are no safe havens for potential perpetrators. This has led to a legal debate on whether the SUA Convention in combination with the counterpiracy provisions of UNCLOS might in fact obligate states to initiate criminal proceedings against suspected pirates in their own domestic courts. One line of argumentation is that the SUA Convention contains an aut dedere - aut iudicare clause which in its sum means that there is an obligation of the state of apprehension to prosecute at least if no other state is prosecuting. ${ }^{55}$ Another line of argumentation is that it is questionable whether the SUA Convention is in fact establishing a general obligation to prosecute or only an obligation to prosecute or extradite if there is an extradition request by another state. Furthermore, it is argued that the provisions of the SUA Convention are not covering the specific situation of counter piracy and that UNCLOS' provisions (even in combination with the provisions of the SUA Convention) are not establishing an obligation to prosecute. The central argument here is that UNCLOS' Article 105 is using the term 'may' in connection with the seizing state's right to initiate criminal proceedings. ${ }^{56}$ State practice in the Horn of Africa region indicates that states do not necessarily accept the idea of a general obligation to prosecute suspected pirates. Thus, there are several examples of a 'catch and release' approach where suspected pirates were released without any further consequences. This can be illustrated by the Danish example: Danish naval forces have seized 295 persons under the suspicion of piracy, and only 50 of those were transferred to prosecution. ${ }^{57} \mathrm{At}$ the same time has the establishment of a system for the prosecution of suspected pirates been a central part in the efforts under the CGPCS and resulted in what can be called 'chain of criminal justice' where one state might arrest the suspected pirates and transfers them to another state which is hosting the criminal proceedings. If convicted, the pirates get transferred to serve their sentence in Somalia. ${ }^{58}$

The SUA Convention does not explicitly deal with possible powers of private actors. However, the Convention

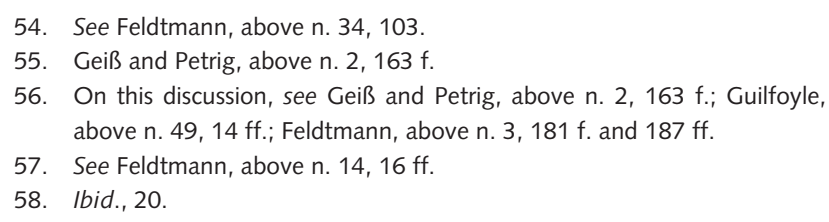


indicates indirectly the master's right to make a civil arrest in connection with attacks against his vessel since Article $8(1)$ provides the master with a right to hand over any person suspected of having carried out an attack on board or against his ship to any state. This must of course mean that the master can withhold the person on board until they can be handed over in due course. The SUA convention does not deal with the issue of the use of force or the right to self-defence; however, the above-mentioned principles are also applied in the context of the SUA Convention.

\subsection{Summing Up}

From the perspective of PCASPs it might not be of particular relevance whether a violent attack against the vessel falls under UNCLOS definition of piracy or not. Private actors are not granted any specific law enforcement powers under UNCLOS, and it is rather questionable if they indeed would be interested in such powers if those were an option. From a PCASP perspective the question of the right to self-defence as a basis for the PCASPs function on board is the central issue at stake. The conclusion from an international law perspective is that an individual's right to self-defence is generally accepted and that the particularities of such a right are determined by domestic legislation or principles. This approach might seem attractive from a domestic flag state perspective and fit fine with the general idea of exclusive flag state jurisdiction in UNCLOS Article 94(1). On the other hand, such a national approach towards the issue at hand has certain inherent risks; national concepts of self-defence vary, for example, in relation to the exact point in time when the right is triggered or to the question of whether the right is only triggered by attacks against human life or also by attacks against property. This means that an act which is a legitimate act of self-defence in one legal system is not necessarily (yet) covered by the concept of self-defence in another system. This means that PCASPs are exercising their task on board with some legal uncertainty and could in a worst-case scenario face criminal proceedings in the flag state of the vessel where the intended act of self-defence was aimed at or in the state where the attackers came from.

From a broader perspective of on-board protection of merchant vessels, the question of the definition of piracy in UNCLOS is rather crucial. If the on-board protection is carried out by a VPD model, the task of protecting a specific vessel might be combined with certain law enforcement elements which can only be exercised by state representatives. The individual's right to selfdefence and the state's right of the use of force in counter piracy are not necessarily identical. Thus, the choice of approach on the national level has implications on the question of whether the employment of on-board protection on merchant vessels is only with a view to a specific protective task under the domestic right of selfdefence or could be also seen in the wider context of the state's approaches and powers under counter piracy and law enforcement.

\section{The Issue of On-board Protection, VPDs and PCASPs in International Law}

The issue of on-board protection of merchant vessels by VPDs or PCASPs is, as mentioned earlier, not directly addressed in UNCLOS or directly regulated in other sources of international law. It can of course be considered whether the general counter-piracy powers under UNCLOS (and under other international laws) might influence the role of VPDs on merchant vessels. In this context, it is important to remember that the right to seizure under UNCLOS, as briefly raised previously, may only be enforced 'by warships or military aircraft, or other ships or aircraft clearly marked and identifiable as being on government service and authorized to that effect' (Art. 107). This implies that if a flag state wishes to use the VPD model and seeks to combine the protection of a specific vessel with a more proactive counterpiracy approach, it might be necessary to formally put the vessel under government service and mark it accordingly. However, if the setting is not a proactive law enforcement approach it could be argued that in a responsive situation, where the pirates attack and are repelled by the VPDs, the VPDs subsequently can arrest the perpetrators and use the powers under UNCLOS even if the vessel was not in government service and marked accordingly. ${ }^{59}$

Another crucial question in connection with the use of VPDs is whether the government personnel on board the merchant vessel can benefit from the immunities connected to warships and government vessels under Articles 95 and 96. In this context, it has been pointed out that in a case of alleged wrongful death of a person mistakenly identified as a pirate, the state embarking the VPDs on the private vessel will be held responsible under state responsibility. Furthermore, while it could be argued for the immunity of the particular guard as a state agent, domestic courts are not necessarily following that line of thought. In the Enrica Lexie incident from 2012, Italian VPDs employed on an Italian merchant vessel shot dead two Indian fishermen who were mistaken for being pirates. The two Italian officers involved in the incident were brought in front of an Indian court, which denied their claim of immunity. ${ }^{60}$ For states which choose to opt for a PCASP model instead of a VPD model, international law has little specific guidance to offer. The law of the sea and in particular UNCLOS is not addressing the topic as such, and the international community could neither achieve any real common ground on the issues at stake in the discus-

59. See D. Guilfoyle, 'Commentary on UNCLOS Article 107', in A. Proelss (ed.), United Nations Convention on the Law of the Sea: A Commentary (2017) 758-9.

60. See Y. Tanaka, 'Dual Provisional Measures Prescribed by ITLOS and Annex VII Arbitral Tribunal: Reflections on the "Enrica Lexie" Incident Case', The Global Community Yearbook of International Law and Jurisprudence (2017) $265 \mathrm{ff}$. 
sion under the CGPCS or anywhere else. This means that international law provides only a general legal background for flag state regulation, but no specific guidelines for the domestic regulation of PCASPs and their employment on board. As a result of this gap in the regulation on the international level, a body of soft-law instruments and self-regulation by the industry has been developed to address the issues at stake and to supplement flag state regulation. Those instruments include, for example, four specific IMO interim recommendations on PCASPs addressed to flag states, coastal/port states, ship owners and security companies and drafted by IMO's Maritime Security Committee (MSC). ${ }^{61}$ Another example is the above-mentioned BMP5 drafted by the shipping industry. ${ }^{62} \mathrm{BMP} 5$ is not dealing primarily with the issue of PCASP as such but is providing more general recommendations '... to help ships plan their voyage and to detect, avoid, deter, delay and report attacks' ${ }^{63}$ BMP5 is as a starting point a nonbinding selfregulatory guidance by the shipping industry to private actors; however, as some of the country reports in this special issue indicate, BMP5 has a strong influence on national regulation, and it can even be argued that some flag states implement BMP5 in their own regulation and thereby transform nonbinding industry self-regulation into binding national legislation. This is for example the case in Denmark, where a ministerial order ${ }^{64}$ is prescribing in its $\S 8$ that ships have to develop their counterpiracy security procedures in the light of the recommendations of the BMP (in its most recent version). What is even more interesting is that the ministerial order in its $\S 13$ criminalises the situation where a ship owner/operator is not following the obligations set out in the ministerial order. This could mean in its consequence that a ship owner could get punished if he is not implementing the recommendations of the BMP in the ship's security procedures.

In the context of nonbinding instruments and self-regulation two more instruments should be briefly mentioned: first, the world's leading shipping association

61. MSC.1/Circ.1443; IMO Maritime Safety Committee, 'Revised Interim Recommendations for Flag States regarding the Use of Privately Contracted Armed Security Personnel on Board Ships in the High Risk Area' (12 June 2015) MSC.1/Circ.1406/Rev.3; IMO Maritime Safety Committee, 'Interim Recommendations for Port and Coastal States regarding the Use of Privately Contracted Armed Security Personnel on Board Ships in the High Risk Area' (16 September 2011) MSC.1/Circ.1408; IMO Maritime Safety Committee, 'Revised Interim Recommendations for Port and Coastal States regarding the Use of Privately Contracted Armed Security Personnel on Board Ships in the High Risk Area' (25 May 2012) MSC.1/Circ.1408/Rev.1; IMO Maritime Safety Committee, 'Revised Interim Guidance to Shipowners, Ship Operators and Shipmasters on the Use of Privately Contracted Armed Security Personnel on Board Ships in the High Risk Area' (25 May 2012) MSC.1/Circ.1405/ Rev.2.

62. Best Management Practice to Deter Piracy and Enhance Maritime Security in the Red Sea, Gulf of Aden, Indian Ocean and Arabian Sea from June 2018 (BMP5) replacing Best Management Practice for Protection against Somalia Based Piracy from August 2011 (BMP4).

63. BMP5, 1

64. Bekendtgørelse om teknisk forskrift om forholdsregler til forebyggelse af pirateri og væbnede overfald på danske skibe, bek. 1084/2011 (23 November 2011).
Baltic and International Maritime Council (BIMCO) has developed a standard contract for the employment of security guards on vessels, the so-called GUARDCON. ${ }^{65}$ GUARDCON seeks to regulate the contractual relationship between the ship owner and the security provider; however, GUARDCON also affects areas of public law, for example, by dealing with the relationship between the master and the team leader of the PCASP. ${ }^{66}$ Second, the International Organization for Standardization (ISO) has developed a standard for the accreditation of Private Maritime Security Companies (PMSCs). ${ }^{67}$

The lack of specific regulation of PCASPs and connected questions in international law combined with the development of soft-law and self-regulation instruments leads to the conclusion that the topic of PCASPs is complex and leads to certain legal uncertainties. IMO's Maritime Safety Committee (MSC) noted in connection with their recommendations that the absence of applicable regulation and industry self-regulation coupled with complex legal requirements gives cause for concern. ${ }^{68}$ While international law is not specifically addressing PCASP, it still provides the general framework for the governance of the oceans and for the regulation on the flag state level. This means that international law is highly relevant in connection with a number of issues which are linked to the use of PCASP, some of these will be briefly raised in the following subsections.

\subsection{Weapons On-board and the Issue of Innocent} Passage

One central issue which has been raised in particular with the question of PCASP, but to a certain extent is also relevant in a VPD context, is the question of whether the fact that a merchant vessel has weapons on board influences its right to innocent passage through a given coastal states' territorial waters. The right to innocent passage is one of the central elements in the balance between the coastal states interest to rule and govern its own territorial waters and flag states' interest of free navigation without any interference. ${ }^{69}$ The right to innocent passage is codified in Article 17 and basically limits a coastal state's jurisdiction on vessels passing thought its territorial waters. Article 18 clarifies passage by stating it 'means navigation through the territorial sea for the purpose of ... traversing that sea without

65. Baltic and International Maritime Council's standard contract for the employment of security guards on vessels (GUARDCON). See BIMCO's webpage, available at: https://www.bimco.org/ (last visited 1 April 2019).

66. GUARDCON, Part II, cl. 8.

67. ISO 28007-1:2015 Ships and Marine Technology - Guidelines for Private Maritime Security Companies (PMSC) Providing Privately Contracted Armed Security Personnel (PCASP) on Board Ships (and Proforma Contract), ISO 28007.

68. IMO Maritime Safety Committee (MSC), 'Revised Interim Guidance to Private Maritime Security Companies Providing Privately Contracted Armed Security Personnel on Board Ships in the High Risk Area' (25 May 2012) MSC.1/Circ.1443, Annex (1).

69. See K. Siig and B. Feldtmann, 'UNCLOS as a System of Regulation and Connected Methodology: Some Reflections', 502 SIMPLY (Marlus) 74 f. (2018). 
entering internal waters or calling at a roadstead or port facility outside internal waters; or ... proceeding to or from internal waters or a call at such roadstead or port facility.... Passage shall be continuous and expeditious.' This means that, for example, a vessel on a journey through the Red Sea passing through a given state's territorial waters would be on a passage according to Article 18. The second criterion is that the passage must be innocent. According to Article 19(1) a passage is innocent 'so long as it is not prejudicial to the peace, good order or security of the coastal State.' This is more specified in the following Subsection (2), which lists a number of activities which result in that the passage should be considered as not innocent. In the context of armed on-board protection litra (a) and (b) are relevant in particular. Litra (a) excludes 'any threat or use of force against the sovereignty, territorial integrity or political independence of the coastal State, or in any other manner in violation of the principles of international law embodied in the Charter of the United Nations' from the concept of innocent, while litra (b) deals with 'any exercise or practice with weapons of any kind'. This could lead to the conclusion that a passage is not innocent if weapons are on board; this would be a hasty conclusion. It is argued in the legal debate that Article 19 describes certain activities which are prejudicial to the peace, good order or security of the coastal state. The carriage of safely stored weapons on a voyage is not in itself a threat or an activity in the sense of Article 19(2) and could, for example, be compared to the carrying of dangerous cargo, which in itself does not contradict innocent passage. It is therefore not convincing to conclude that weapons on board in itself would contradict innocent passage. ${ }^{70}$ Things get more complicated if the weapons are actually used, even in selfdefence, and it is argued that the wide wording of Article 19(2) litra (b) referring to 'any exercise or practice with weapons' indicates that the use of weapons for whatever reason interferes with the concept of innocent passage. ${ }^{71}$ And even if the use of weapons in selfdefence would not interfere with the concept of innocent passage, it could still trigger the right of the coastal state to investigate the incident and exercise criminal jurisdiction under Article 27(1)(a) or (b).

In addition, the foregoing conclusions and considerations are not unopposed: the reality in the Horn of Africa region indicates, for example, that some coastal states draw a different legal conclusion and perceive safely stored weapons on board as incompatible with the concept of innocent passage with the consequence that they reserve the option of law enforcement against vessels passaging with weapons on board. ${ }^{72}$ The legal uncertainties in connection with the carriage of weapons and the concept of innocent passage is most likely a factor in the development of so-called floating armouries, which

70. Oehmke, above n. 40, 226-30.

71. Ibid., 230-3.

72. This conclusion was supported by a Danish questionnaire-based study conducted by the University of Southern Denmark. The results of this study are with the author. briefly described are commercial vessels placed out of territorial waters and functioning as a kind of sea-based weapon and equipment storage facility. The establishment of floating armouries is not uncontroversial; some states in the Indian Ocean region perceive them as a protentional threat to security in the region. Floating armouries lead to a number of legal concerns and legal challenges; they are not explicitly regulated in international law and in fact subject to the general regulation of vessels and the regulation by the flag state and the state where the company is registered. ${ }^{73}$ Nevertheless, today they are part of the reality in the wider Indian Ocean region. ${ }^{74}$ It is therefore interesting to see whether the flag states' models of regulation of on-board protection presented in this special issue address the question of how to get weapons transported and on-board or not or even might prohibit the use of the services of floating armouries.

\subsection{The Issue of the Role of the Master and the Team Leader}

A very crucial, but also somewhat complicated, issue in connection with the employment of PCASPs (and to a far lesser extent of VPDs) is the role of the master and the division of powers between the master and the team leader. The problem in a nutshell can be summarised by the question of who has the final say in issuing the weapons and ordering the end of the self-defence. The starting point for the legal considerations is the general status and role of the master in the law of the sea. The master is the final authority on board. In addition, some flag states might understand the master, under certain circumstances, as a formal representative of the state. A central element in the master's function is to ensure the safety of the vessel and all persons on board. This is, for example, emphasised in the International Convention for the Safety of Life at Sea (SOLAS) Regulation 34.1: neither the owner, the charterer, the operating company nor any other person can prevent or restrict decisions taken by the master with view to the safety of life at sea. The dangers of a piracy attack are an issue of the safety of life at sea and therefore under Regulation 34.1. On the other hand, it can be argued that the master does not have the necessary training and tactical knowledge in this arena; this is the qualification the team leader and his personnel should add. Furthermore, the right to self-defence is an individual right and cannot be easily overruled by a master. ${ }^{75}$

These here only briefly raised aspects illustrate that the employment of PCASP creates a certain overlap or clash of competences and powers. The shipping industry and

73. Floating armouries and connected legal questions are a topic several times raised under the discussion of the CGPCS, see, e.g., Final Communiqué of the 21st Plenary Session of the CGPCS (12-13 July 2018), para. 20, available at: www.lessonsfrompiracy.net/files/2018/07/ Communique-of-the-CGPCS-21st-Plenary-Session.pdf (last visited 1 April 2019).

74. A. Wilpon, 'Floating Armories: A Legal Grey Area in Arms Trade and the Law of the Sea', 48 Georgetown Journal of International Law $873 \mathrm{ff}$. (2016).

75. See Oehmke, above n. 40, 201-6. 
other maritime stakeholders have tried to deal with the problems at hand by issuing guidelines and thereby trying to provide for a functioning division between the role of the master and the team leader. One example is BIMCO's widely used standard contract GUARDCON, which in Clause 8 on the one hand tries to confirm the authority of the master and on the other hand puts the decision of the use of force on the team leader while the master keeps the overruling right to end the self-defence. $^{76}$ It is not certain that GUARDCON's model will solve all possible conflicts, but the example shows that the maritime stakeholders seek to create their own regulation if the law is of little guidance. It is interesting to see in the following country reports in this special issue if the issue of division of powers between the master and the team leader is explicitly dealt with on the national level.

The question of division of powers is linked to another question which could be raised on the national level. Who is held responsible if things go wrong? If, for example, a master after consulting the team leader issues the weapons and a PCASP wrongly shoots an innocent fisherman, could the master be criminally liable as an associate to the crime? The answer towards that question has ultimately to be answered on the level of national criminal law (e.g., of the flag state or the state of the victim) and depends on the concept of participation in a crime. In general, it can be assumed that it seems possible, of course depending on the specific circumstances of a given case, that a master can be liable as an associate to a crime committed by a PCASP if he is involved in the wrongful decision to open fire.

\subsection{The Duty to Render Assistance and the Protection of Vessels}

One of the deeply rooted principles of the law of the sea, which today is codified in a number of different legal acts, is the duty to render assistance. The duty is, for example, codified in UNCLOS Article 98 and SOLAS Regulation 33. The specific wording of the codification in the different legal acts varies; the wording in SOLAS seems, for example, to indicate a direct obligation of the master while the provision in UNCLOS puts the obligation on the flag state which subsequently has to ensure that the master is following the duty. ${ }^{77}$ Beyond those differences, all codifications have some shared core elements. One of those elements is that the duty to render assistance is triggered by a distress situation, in particular where lives are at risk. The crucial question here is if there is a distress situation where the safety of the vessel and its crew is at peril and not hhy this situation has occurred. Another of these core elements is the principle of own safety first. The duty to render assistance is limited by (or preconditioned by) the safety of the rescuer's own vessel and crew.

76. Ibid., 205-6.

77. See B. Feldtmann, 'What Happens After the Defense? Considering "Post Incident" Obligations of Masters from the Perspective of International and Danish Law', 46 Ocean Development \& International Law (ODIL) 98 ff. (2015); Oehmke, above n. 40, 206 ff.
In the context of on-board protection, the duty to render assistance might be relevant in two situations. First, a duty to render assistance can be triggered if a vessel has employed PCASPs or VPDs and gets a distressed call from another vessel under attack. It is argued that the specific duty would be here to get to the vessel under attack and assist by using the weapons to repel the attacker. ${ }^{78}$ Second, the duty to render assistance comes into play if the PCASPs or VPDs have repelled an attack and the attackers are seriously harmed or their vessel is unable to navigate or is sinking. ${ }^{79}$

When considering the duty to render assistance it must be kept in mind that the duty, as mentioned earlier, is limited by the principle of own safety first. This means that the master has a certain room for assessing the specific situation at hand and the inherent risks. This means also that the master must not necessarily pick up the same persons who attacked his vessel only a few minutes ago. However, the master must be aware of the duty and take it into account. ${ }^{80}$ If not, he bears the risk of criminal prosecution before domestic courts.

In connection with possible obligations after a repelled attack another question might come into play. Are the PCASPs or the VPDs obliged to try to arrest the perpetrators? As shown earlier, state representatives have under certain circumstances law enforcement powers against suspected pirates. It is, however, from an international law perspective questionable if those powers can be understood as an actual obligation. Also, PCASPs have, as mentioned earlier, the right to perform a civil arrest with a view to handing the perpetrators over to the authorities. This is a right but not an obligation. If PCASPs or VPDs do in fact arrest suspected pirates a number of connected issues arise, such as their treatment on board and other human rights issues.

\subsection{Summing Up}

The international law of the sea does not directly deal with the issue of armed on-board protection of merchant vessels; it is neither encouraging nor prohibiting such approaches. Flag states that wish to regulate the issues at hand receive only limited guidance from the law of the sea; it is merely functioning as a general legal framework, when PCASPs or VPDs are employed. The employment of armed guards leads to complex and diverse legal questions and one of the conclusions in the light of the above brief considerations is that it seems that soft-law instruments play a crucial role in the attempt to clarify the issues at stake and to operationalise the general rules and principles.
78. See D. König and T. Salomon, 'Private Sicherheitsdienste auf Handelsschiffen; Rechtliche Implikationen', 2 PiraT-Arbeitspapire zur Maritimen Sicherheit (2011)

79. Feldtmann, above n. 77, $98 \mathrm{ff}$

80. Ibid., $103 \mathrm{ff}$. 


\section{Concluding Remarks}

The issue of armed on-board protection of merchant vessels is not an easy one, neither in the public debate nor from a legal perspective. PCASP and VPD are, as the country reports in this special issue illustrate, topics which lead to diverse approaches and models of regulation. International law is not providing much guidance on the issues at stake; it neither explicitly prohibits nor actively supports the use of armed on-board protection and seems to express no specific preference for either the PCASP or VPD model. The task of on-board protection of specific merchant vessels is as such not part of the counter-piracy powers under UNCLOS, and the legal status of different types of guards give rise to a number of legal concerns. The PCASP and the VPD models have from an international law perspective some shared legal challenges to face, as well as challenges more specifically relevant for one or the other model. One of the conclusions which can be drawn from the international perspective is that the use of on-board protection give rise to certain legal uncertainties; some of those are connected to the fact that coastal states (or other flag states) might exercise an interpretation of international law which could be questionable but nevertheless could have an impact on the guards employed on foreign vessels. This means that every flag state and every ship owner must reflect on the issues at stake and the connected legal risks and on this basis choose the way to proceed.

One consideration that from an international perspective could be raised is that the lack of international regulation of on-board protection, the right of self-defence and the connected security marked could lead to a 'race to the bottom', meaning that certain flag states, for example, flag states which could be perceived as 'flags of convenience $^{81}$ with little interest in and control of their ship register and the actual conditions on board, could give way to a situation where there is no control with armed protection and no legal guidance for the use of weapons on board. It can be argued that a part of the shipping industry, which perceives themselves as 'responsible quality shipping', could in this sense have an interest in at least some binding minimum standards for all PCASPs and thereby avoid unfair competition from the 'race to the bottom'.

Another conclusion of the international law perspective is that a lack of formal, binding international regulation in the field gives way to a soft-law approach, meaning nonbinding attempts of regulation in different fora. This can be perceived as a smooth and flexible way to deal with the problem at hand; the other side of the medal is, however, that the problem is not necessarily solved. Nonbinding regulation might work well if it is widely accepted and implemented; if it is not followed in real life, it could be argued that it functions more as a kind of alibi. One possible way to strengthen the impact of nonbinding international rules and guidelines would be where states decide to implement soft-law principles or rules in their own legislation; the country reports in this special issue are casting some light on the question of whether this is the case or not. 